\title{
Selfing and sibship structure in a two-cohort stand of maritime pine (Pinus pinaster Ait.) using nuclear SSR markers
}

\author{
Santiago C. González-Martíneza,b, Sophie Gerberc, María-Teresa Cerverad, \\ José-Miguel Martínez-Zapaterd, Ricardo Alía ${ }^{\mathrm{a}}$ and Luis Gil ${ }^{\mathrm{b} *}$ \\ ${ }^{a}$ Unidad de Genética Forestal, CIFOR-INIA, PO 8111, 28080 Madrid, Spain \\ b Unidad de Anatomía, Fisiología y Genética, ETSIM, Ciudad Universitaria s/n, 28040 Madrid, Spain \\ ${ }^{\mathrm{c}}$ Laboratoire de génétique et amélioration des arbres forestiers, INRA, BP 45, 33611 Gazinet Cedex, France \\ d Departamento de Genética Molecular de Plantas, Centro Nacional de Biotecnología, CSIC, Campus Universidad Autónoma de Madrid \\ en Cantoblanco, 28049 Madrid, Spain
}

(Received 19 December 2001; accepted 25 June 2002)

\begin{abstract}
The genetic relatedness between pairs of trees was analyzed in an adult stand of maritime pine with abundant advanced natural regeneration using three highly polymorphic microsatellites $(E P>90 \%)$. Only five possible self-pollinated offspring were found, thus meaning a maximum selfing rate based on dispersed progeny of 3.8\%. Likelihood ratios were used to detect sib relationships in both mature trees and natural regeneration. The percentage of half-sib and full-sib links in the adult trees was $19.09 \%$ and $1.82 \%$, respectively, thus indicating a low level of genetic relatedness due to sib relationships $(\approx 3 \%)$. Similar results were obtained for the natural regeneration but with a higher percentage of full-sibs (2.37\%) and a greater family size. A high amount of pollen gene flow from outside the plot is suggested to explain the low genetic relatedness found. Collection of seedlots in this stand seems adequate as a low level of inbreeding is expected.
\end{abstract}

mating system / genetic relatedness / microsatellites / Pinus pinaster / Mediterranean region

Résumé - Étude de l'autofécondation et apparentements dans un peuplement de pin maritime, constitué de deux cohortes, à l'aide de marqueurs microsatellites. L'apparentement génétique entre paires d'arbres a été analysé dans une parcelle de pins maritimes adultes dotée d'une régénération naturelle abondante et avancée, en utilisant trois marqueurs microsatellites très polymorphes (probabilités d'exclusion $>90 \%$ ). Seuls cinq descendants issus d'autofécondations probables ont pu être détectés, indiquant un taux maximum d'autofécondation de $3,8 \%$. Des rapports de vraisemblance ont été utilisés pour détecter les relations d'apparentement chez les arbres adultes et dans la régénération naturelle. Les pourcentages de demi- et de pleins-frères observés parmi les arbres adultes ont été estimés à 19,09 et 1,82\% respectivement, indiquant ainsi un faible taux d'apparentement génétique dû aux fratries $(\approx 3 \%)$. Des résultats similaires ont été obtenus pour la régénération naturelle, mais avec un pourcentage de pleins-frères plus élevé $(2,37 \%)$ et des tailles de familles supérieures. Un flux de pollen élevé provenant de l'extérieur de la parcelle doit pouvoir expliquer le faible apparentement observé. La récolte de lots de graines dans cette parcelle semble adéquate puisqu'un faible taux d'autofécondation y est attendu.

système de reproduction / apparentement génétique / microsatellites / Pinus pinaster / région méditerranéenne

\section{INTRODUCTION}

The mating pattern of a species determines partly the distribution of genotypes within populations and influences the degree of differentiation among populations, thus affecting significantly its population structure and dynamics. In plant species, high relatedness within populations has two major consequences [17]: (a) it increases the level of kin competition between individuals; and (b) mating between relatives (i.e. biparental inbreeding) may produce a reduction of fitness due to inbreeding depression. Moreover, with biparental inbreeding the genetic relatedness between parents and progenies is

Correspondence and reprints

Tel.: +34-91-3367113; fax: +34-91-5439557; e-mail: lgil@ montes.upm.es greater than when mating is between unrelated individuals, thus reducing the classic two-fold evolutionary advantage of selfing ([49] and references within) and promoting the evolution of outcrossing [40]. Relatedness within populations, either by selfing or mating between related individuals, has also practical implications in conservation genetics of forest trees. Sampling strategies for ex situ preservation of forest genetic resources are severely conditioned by the level of relatedness found in a population [1,9]. Moreover, a forest management that preserves genetic integrity and the potential for evolution in native populations precludes the application of genetic information in practical forestry. Studies about genetic 


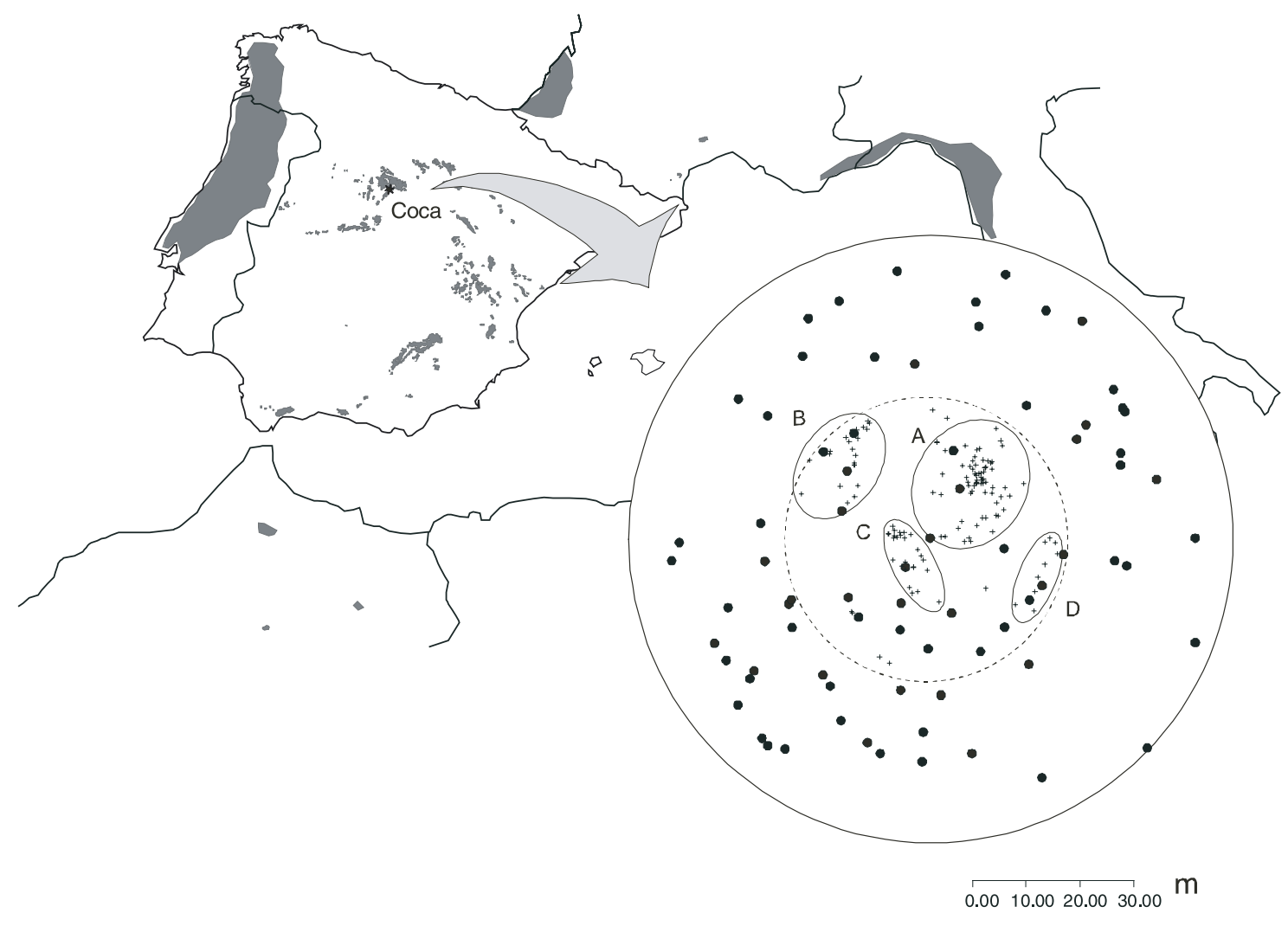

Figure 1. Location of the study plot and spatial distribution of mature trees (circles) and offspring (crosses) within the plot. Four main groups of offspring are shown (A to D). The shadowed area represents the range of the species.

relatedness in native stands of forest species are scarce even when they can produce valuable data for forest management. This information could be used, for instance, to determine the minimum acceptable distance between seed trees sampled for reforestation or the validity of progeny tests based on openpollinated families [45].

The study of relationships between individuals is a common application of molecular markers (see [39] for a review). Molecular markers, such as AFLPs (amplified fragment length polymorphisms) and nuclear microsatellites (nuclear SSRs) have been used to directly estimate family links in many organisms $[15,36,46]$. Several parameters based on molecular markers have been developed to estimate pairwise genetic relatedness $[25,26,37,38]$. In addition, the estimation by means of likelihood ratios allows simple relationships (for example, full-sib vs. half-sib) to be compared [47, 48]. For instance, Meagher [28] found this approach useful to study patterns of male reproductive success in a natural population of Chamaelirium luteum.

Maritime pine (Pinus pinaster Ait.), a Mediterranean species with a scattered distribution in southwestern Europe, is the more spread conifer species in Spain nowadays (near 1200000 ha). Its wide distribution and the variety of sites occupied have made $P$. pinaster a species of high relevance in Iberian forestry landscape $[13,19]$. Maritime pine populations from the Iberian Peninsula show high levels of genetic diversity as well as an important genotype-by-environment interaction that favours local adaptation to ecological conditions $[3,4,41]$. This occurs in spite of extensive historical gene flow $(\mathrm{Nm}=3.02$ [41] $)$ and a well-adapted reproductive strategy to Mediterranean conditions [29]. In 1999, an intensive sampling plot (ISP) was located in a typical Mediterranean location of maritime pine in central Spain (Coca) to study gene flow patterns and within-population structure. In this plot, a finescale genetic structure in offspring, due to restricted seed gene flow, and a lack of genetic structure in mature trees were found [20].

In this study, we used three highly polymorphic nuclear microsatellites to further investigate the ISP of Coca in two new aspects: (a) the level of selfing within the population based on dispersed progeny; and (b) the sibship structure both of mature trees and natural regeneration. Likelihood ratios were used to estimate the number of full-sibs and half-sibs within the stand and to compute the biparental inbreeding due to sib relationships.

\section{MATERIALS AND METHODS}

\subsection{Plant material}

The studied stand is situated at $755-810$ m.a.s.l. in a flat sandy region in the Castilian Plateau, central Spain (figure 1). The climate in this area is dry Mediterranean, with annual average rainfall and 
temperature of $432 \mathrm{~mm}$ and $12.3^{\circ} \mathrm{C}$, respectively, and a pronounced summer drought. The stand basal area is $17.77 \mathrm{~m}^{2} \mathrm{ha}^{-1}$ and the density is 120.96 stems ha $^{-1}$. Silviculture in the area is based on natural regeneration following a shelterwood system adapted to resin production. Two cohorts of trees can be clearly distinguished: (a) mature trees ranging from 32 to 140 years old; and (b) seedlings and saplings (less than 25 years old) produced by advanced regeneration (i.e. before the silvicultural treatments) of the mature trees. The seedlings and saplings were clumped in four main clusters as shown by a nearest neighbour cluster analysis based on the squared Euclidean distance (figure 1). Needle samples from all mature maritime pine trees within a circular plot of $50 \mathrm{~m}$ in radius $(\mathrm{n}=76)$, and all seedlings and saplings taller than $20 \mathrm{~cm}$ within a central subplot of $25 \mathrm{~m}$ were collected $(\mathrm{n}=132)$. Because only dead trees had been removed from the main crop during management operations, the stand was considered to represent the natural conditions of this species.

\subsection{Molecular markers}

The development of microsatellites in Pinus species has been reported to be difficult due to the size and complexity of their genome $[23,50]$. In Pinus pinaster, screening of a library enriched with CA and GA repeats and cross-species amplification were quite unsuccessful and only three primer pairs produced single variable bands segregating in a Mendelian manner ([27], our unpublished results). Genomic DNA was extracted from needles using a modified protocol from Dellaporta et al. [14]. One primer pair (FRPP94) was scored using a LI-COR 4000 automatic sequencer (LI-COR Inc., NE, USA) following protocols extensively described in Mariette et al. [27]. The other two (FRPP91 and ITPH4516) were analysed as follows. The amplification was carried out in a Perkin Elmer GeneAmp PCR system 9600, using 0.5 U of Taq Polymerase (Boehringer), and $20 \mathrm{ng}$ of DNA in a total volume of $10 \mu \mathrm{L}$ containing $2 \mathrm{mM}$ of each dNTPs, $2 \mu \mathrm{M}$ of each primer and 5\% DMSO to enhance specific amplification. The concentrations of $\mathrm{MgCl}_{2}$ were $1.5 \mathrm{mM}$ for ITPH4516 and $2 \mathrm{mM}$ for FRPP91. Forward primers were labelled with ${ }^{33 \gamma}$ P-ATP. Cycling consisted of an initial denaturation of $5 \mathrm{~min}$ at $94{ }^{\circ} \mathrm{C}$, followed by 20 cycles with variable annealing temperature ("touch down"): $30 \mathrm{sec}$ denaturation $\left(94^{\circ} \mathrm{C}\right)$; $30 \mathrm{sec}$ annealing (from $63{ }^{\circ} \mathrm{C}$ to $61{ }^{\circ} \mathrm{C}$ with a decrease of $0.1^{\circ} \mathrm{C}$ every cycle) and $45 \mathrm{sec}$ extension $\left(72^{\circ} \mathrm{C}\right)$; and 15 cycles with constant annealing temperature: $30 \mathrm{sec}$ at $94{ }^{\circ} \mathrm{C}, 30 \mathrm{sec}$ at $61{ }^{\circ} \mathrm{C}$ and $45 \mathrm{sec}$ at $72{ }^{\circ} \mathrm{C}$; and a final extension of $5 \mathrm{~min}$ at $72{ }^{\circ} \mathrm{C}$. Amplification products were denatured by adding $20 \mu \mathrm{L}$ of formamide buffer $(98 \%$ formamide, $10 \mathrm{mM}$ EDTA pH 8.0, $0.05 \%$ bromophenol blue and $0.05 \%$ xylene cyanol), heated 3 min at $94{ }^{\circ} \mathrm{C}$ and $1.5 \mu \mathrm{L}$ of the samples were loaded in a denaturing gel containing $6 \%$ acrylamide/bisacrylamide (19:1), 7.5 $\mathrm{M}$ urea and $1 \mathrm{X}$ TBE. Electrophoresis was performed at $95 \mathrm{~W}$ and $45^{\circ} \mathrm{C}$ of plate temperature using a $1 \mathrm{X}$ TBE running buffer for approximately $3 \mathrm{~h} 30 \mathrm{~min}$. Gels were dried and exposed to X-ray film for 1-2 days. Allele sizes were determined by comparison to known sequences and using a 100 bp standard marker (Gibco BRL) as length size reference. Additionally, four previously scored individuals were run in all gels to ensure gel-to-gel consistency.

\subsection{Data analysis}

\subsubsection{Exclusion probabilities}

The performance of nuclear microsatellites in the estimation of mating system parameters was analysed using exclusion probabilities $(E P)$. Exclusion probabilities (the average probability of excluding, by genetic analysis alone, a given individual/couple as a father/ parent/parent pair of an offspring, when it is not a true father/parent/ parent pair) for codominant markers were computed following Jamieson and Taylor [22]. Three different exclusion probabilities were calculated: single parent exclusion, when a potential parent and an offspring are compared without any other information; paternity exclusion, when the genotype of the mother is known, as is the case when seed crops are harvested from identified trees; and, parent-pair exclusion, when pairs of parents are checked against a potential offspring. For one locus with $n$ different alleles, each $i$ allele having a $p_{i}$ frequency in the population, let $a_{k}$ be:

$$
a_{k}=\sum_{i=1}^{n} p_{i}^{k}
$$

Then, the different exclusion probabilities are written as follows:

$$
\begin{aligned}
& \text { Single parent: } \quad E P=1-4 a_{2}+2 a_{2}^{2}+4 a_{3}-3 a_{4} ; \\
& \text { Paternity: } \quad E P=1-2 a_{2}+2 a_{3}+2 a_{4}-3 a_{5}-2 a_{2}^{2}+3 a_{2} a_{3} ; \\
& \text { Parent pair: } \quad E P=1+4 a_{4}-4 a_{5}-3 a_{6}-8 a_{2}^{2}+8 a_{2} a_{3}+2 a_{3}^{2} .
\end{aligned}
$$

For $K$ independent loci, the overall exclusion probabilities are calculated as:

$$
E P=1-\prod_{i=1}^{k}\left(1-E P_{i}\right)
$$

where $E P_{i}$ is the exclusion probability at a locus $i$.

\subsubsection{Selfing within the stand}

Seedlings and samplings collected in the plot were used to estimate the selfing rate based on dispersed progeny, that is, the number of selfs that have a high probability of reaching maturity (in this case, selfs older than four years). The selfing rate based on dispersed progeny was estimated using exclusion analysis (see [42] for a review). Exclusion analysis uses multilocus genotypic data to differentiate between genetically compatible and incompatible parents for a given offspring. In this case, the selfing rate was obtained computing the percentage of established offspring with genotypes that can be generated by selfing of the mature trees within the plot.

\subsubsection{Sibship structure}

The identification of the most-likely half-sib and full-sib pairs was done using likelihood ratios (LOD-scores). To classify pairs of individuals by relatedness (full-sibs, half-sibs and unrelated), LODscores were calculated following the formulas of Brenner [8]. For each pair of trees A and B genotyped at $\mathrm{N}$ loci, the half-sib and fullsib LOD-scores were calculated as follows:

Half-sibs: LOD - score $(\mathrm{A}$ and $\mathrm{B}$ half - sibs $)=$

$$
\sum_{\text {locus }=1}^{\mathrm{N}} \log _{\mathrm{e}} \frac{\mathrm{P}(\mathrm{A} \text { and } \mathrm{B} \text { half }- \text { sibs })}{\mathrm{P}(\mathrm{A} \text { and } \mathrm{B} \text { unrelated })}
$$

Full-sibs: LOD - score $(\mathrm{A}$ and $\mathrm{B}$ full - sibs $)=$

$$
\sum_{\text {locus }=1}^{\mathrm{N}} \log _{\mathrm{e}} \frac{\mathrm{P}(\mathrm{A} \text { and } \mathrm{B} \text { full }-\mathrm{sibs})}{\mathrm{P}(\mathrm{A} \text { and } \mathrm{B} \text { unrelated })}
$$

where $\mathrm{P}(\mathrm{R})$ is the likelihood of a relationship of type $\mathrm{R}$. Using the observed allele frequencies and assuming that the current population originated from a previous random mating generation, 10000 pairs of unrelated individuals, 10000 pairs of half-sibs, and 10000 pairs of full-sibs were generated. The LOD-scores were computed for each pair and plotted against each other in order to define the threshold values for a given relationship [6]. To evaluate the performance of this test, six sets with different sibship composition of 10000 pairs of 
Table I. Estimated exclusion probabilities (single parent, paternity and parent pair) using three nuclear SSRs.

\begin{tabular}{lccc}
\hline & Single parent & Paternity & Parent pair \\
\hline FRPP91 & 0.6853 & 0.8134 & 0.9441 \\
FRPP94 & 0.3284 & 0.5070 & 0.6984 \\
ITPH4516 & 0.6320 & 0.7755 & 0.9216 \\
All & 0.9222 & 0.9794 & 0.9987 \\
\hline
\end{tabular}

individuals were simulated. Home-made $\mathrm{C}$ programs were use for log-likelihood calculations and simulations.

After the detection of the most-likely relationship between each pair of individuals (full-sibs, half-sibs or unrelated), an estimation of the population kinship coefficient based only on sib relationships $(P)$ can be obtained by the following formula:

$$
P=\frac{n_{F S} \times r_{F S}+n_{H S} \times r_{H S}}{n}
$$

where $n_{F S}$ and $n_{H S}$ are the number of full-sibs and half-sibs, respectively; $r_{F S}$ and $r_{H S}$ are the coefficients of full-sibs (1/4) and half-sibs (1/8), respectively; and $n$ is the total number of possible pairs. The sib-based kinship coefficient was calculated separately for mature trees and advanced regeneration. This coefficient was also computed for each of the groups of advanced regeneration detected by the cluster analysis (see Plant Material).

\section{RESULTS}

The pooled exclusion probabilities for nuclear microsatellites were over $90 \%$ in all the cases (table I). As expected, the best discrimination was obtained in parent pair analysis. In this type of analysis, the most polymorphic markers considered alone (ITPH4516 and FRPP91) reached exclusion probabilities of 0.92 and 0.94 , respectively. The high resolution obtained after pooling the three SSR markers allowed the estimation of the selfing within the stand based on dispersed progeny $(E P=0.92)$. Only five possible self-pollinated offspring were found within the plot, thus meaning a maximum selfing rate of $3.8 \%$.

Simulated distributions for LOD-scores of unrelated, halfsib and full-sib individuals are shown in figure 2. Based on these distributions, the individuals of a given pair were considered half-sibs if half-sib LOD-score $>0.1036$ and fullsib LOD-score $>-0.9349$, (not being additionally classified as full-sibs) full-sibs if half-sib LOD-score $>1.3833$ and full-sib LOD-score $>1.6046$, and unrelated in other case. Although the distribution curves overlap, there is a good discrimination between sib relationships. This is particularly true in the case of low relatedness within the stand, where $70-80 \%$ of the sib relationships are correctly identified (table II). The number of half-sib and full-sib pairwise relationships in the adult cohort (2850 pairs) was $554(19.09 \%)$ and $52(1.82 \%)$, respectively. Most of the trees have at least one full-sib within the plot (around $80 \%$ ) and all of them have at least one half-sib (figure 3). Fairly similar results were obtained for the
Table II. Percentage of correct decisions obtained with our discrimination test (see further explanation in the text) applied on six datasets of 10000 simulated pairs with different sibship composition.

\begin{tabular}{ccccc}
\hline \multicolumn{2}{c}{ Percentage of relatedness type } & \multicolumn{2}{c}{ Percentage of correct decisions } \\
\hline Full-sib & Half-sib & Unrelated & Mature trees & $\begin{array}{c}\text { Advanced } \\
\text { regeneration }\end{array}$ \\
\hline 0 & 0 & 100 & 78.06 & 77.79 \\
2 & 20 & 78 & 71.23 & 71.92 \\
5 & 20 & 75 & 70.33 & 70.81 \\
25 & 25 & 50 & 65.24 & 64.53 \\
2 & 50 & 48 & 61.15 & 61.79 \\
33 & 33 & 33 & 59.69 & 60.34 \\
\hline
\end{tabular}
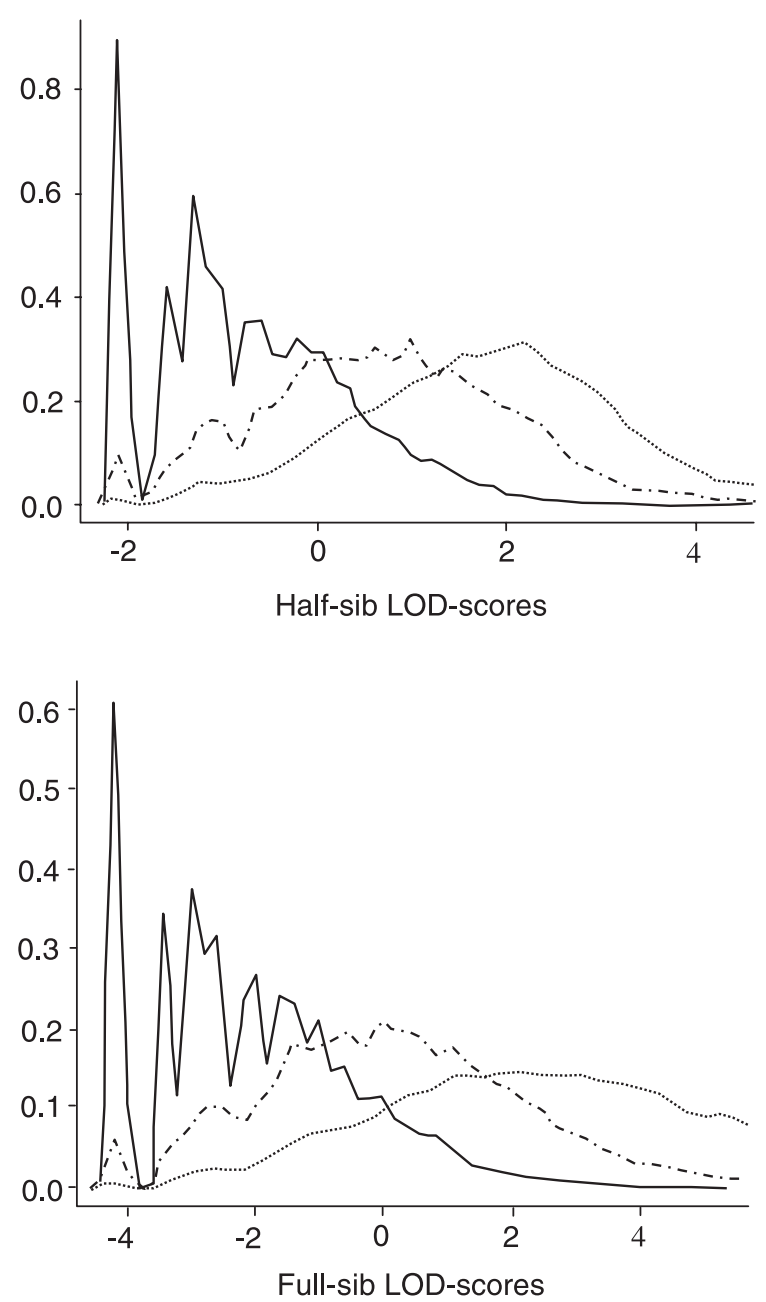

Figure 2. Distributions of half-sib (up) and full-sib (down) LODscores of 10000 simulated pairs of unrelated (solid line), half-sib (alternative point-dash line) and full-sib (dashed line) individuals.

advanced regeneration cohort but with a higher percentage of full-sibs $(2.37 \%)$, in particular in cluster B (6.32\%; table III), and a greater family size. 

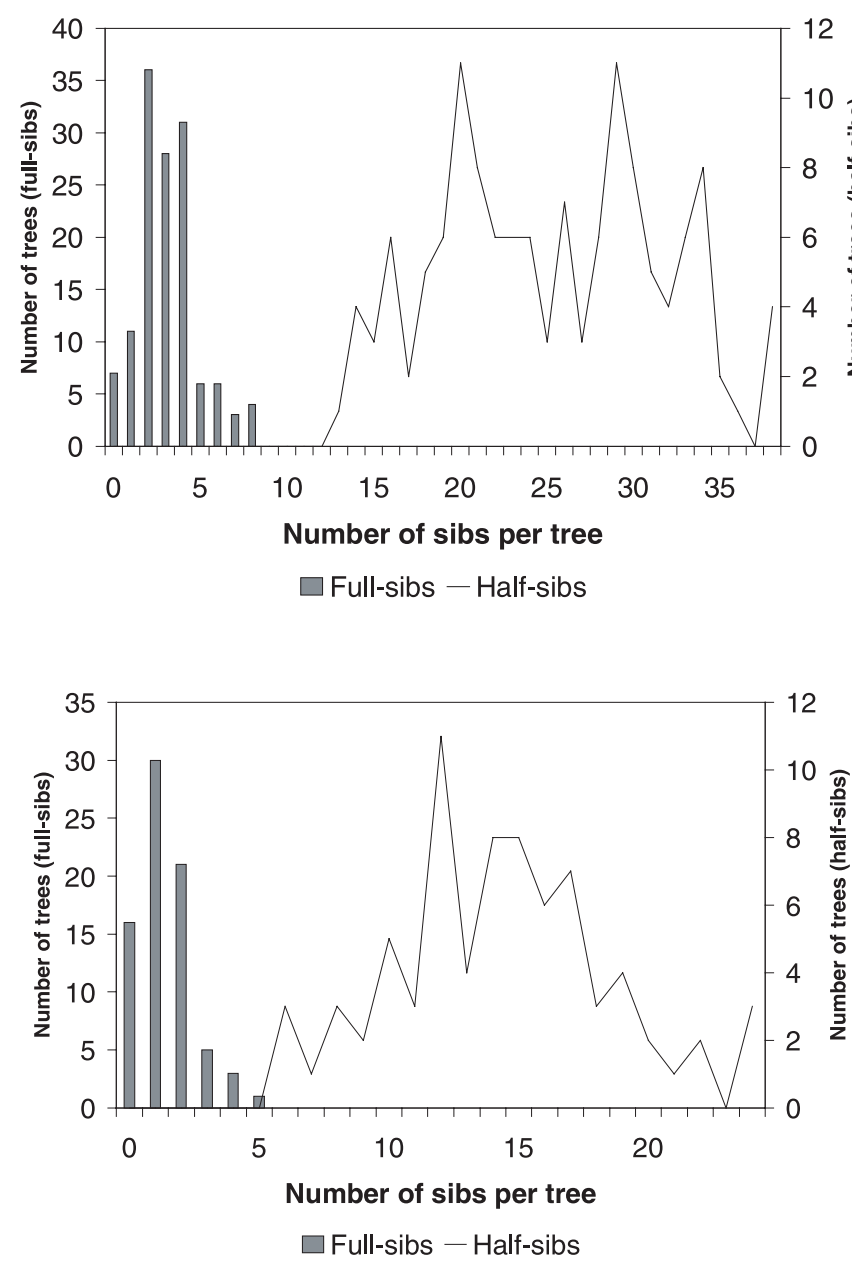

Figure 3. Distributions of the number of full-sibs and half-sibs per tree for advanced regeneration (up) and mature trees (down).

Global genetic relatedness based on sib relationships was low for both cohorts, 0.028 for the adult cohort and 0.030 for the advanced regeneration cohort. This coefficient corresponds to the inbreeding that would be introduced in the next generation assuming random mating and is expected to be similar in different cohorts when selfing is absent or very low. Not important differences were found between clusters of regeneration, with the possible exception of cluster B that presented a higher genetic relatedness (0.045) due to the existence of a relatively high number of full-sib relationships (12 from 190 pairs)

\section{DISCUSSION}

Nuclear microsatellite markers have been shown to provide extremely high exclusion probabilities both in parentage and paternity analysis $[2,18,46]$. To date, only the three nuclear SSR markers used in this study are available in maritime pine. However, the overall exclusion probabilities are equivalent to 26 independent allozyme loci in paternity and parent-pair analysis and to 61 in single-parent analysis (mother unknown),
Table III. Sibship structure for different clusters of advanced regeneration and all the seedlings and saplings pooled.

\begin{tabular}{|c|c|c|c|c|c|}
\hline Cluster & $n$ & $\begin{array}{c}\text { Possible } \\
\text { pairs of } \\
\text { individuals }\end{array}$ & $\begin{array}{c}\text { Number of } \\
\text { half-sib } \\
\text { pairs }(\%)\end{array}$ & $\begin{array}{c}\text { Number of } \\
\text { full-sib } \\
\text { pairs }(\%)\end{array}$ & $\begin{array}{l}\text { Kinship coefficient } \\
\text { based on sibs }(P)\end{array}$ \\
\hline A & 69 & 2346 & $\begin{array}{c}477 \\
(20.33 \%)\end{array}$ & $\begin{array}{c}58 \\
(2.47 \%)\end{array}$ & 0.032 \\
\hline B & 20 & 190 & $\begin{array}{c}45 \\
(23.68 \%)\end{array}$ & $\begin{array}{c}12 \\
(6.32 \%)\end{array}$ & 0.045 \\
\hline $\mathrm{C}$ & 25 & 300 & $\begin{array}{c}72 \\
(24.00 \%)\end{array}$ & $\begin{array}{c}9 \\
(3.00 \%)\end{array}$ & 0.038 \\
\hline D & 9 & 36 & $\begin{array}{c}9 \\
(25.00 \%)\end{array}$ & $\begin{array}{c}0 \\
(0.00 \%)\end{array}$ & 0.031 \\
\hline All & 132 & 8646 & $\begin{array}{c}1663 \\
(19.24 \%)\end{array}$ & $\begin{array}{c}205 \\
(2.37 \%)\end{array}$ & 0.030 \\
\hline
\end{tabular}

when an average polymorphic allozyme locus in the studied area (a locus with three alleles in frequencies of $0.83,0.15$ and 0.02 [41]) was considered. In a mixed stand of European oaks (Quercus robur and Quercus petraea), Gerber et al. [18] showed that six highly polymorphic microsatellite markers (average number of alleles $=21.7$; average Nei's expected heterozygosity $=0.87$ ) were sufficient to obtain a power higher than $95 \%$ in parentage analysis and to avoid biases due to cryptic gene flow.

Coniferous forest trees are wind-pollinated and typically have high proportions of outcrossed progeny $(>0.80)$. The outcrossing in Pinus pinaster $(\approx 0.96)$ was on par with observations in other conifers. However, two sources of bias could affect our estimation: (a) in spite of high exclusion probabilities, exclusion analysis has low power when the number of potential parents in the population is high [12]; and (b) selfs generated by parent trees outside the plot were not considered. In Pinus species, selection against inbreeds is expected to be extensive at the seed stage ([24] and references within) whereas it has only been shown in some species to occur shortly after germination (Pinus leucodermis [33], Pinus sylvestris [34]). In maritime pine, most lethal or sublethal alleles are probably eliminated during seed formation and germination as well as during the first growing season. In a study performed in two coastal dune stands of the Medoc region (western France), Baradat and Marpeau [5] estimated an outcrossing rate after a first growing season in the nursery not significantly different from $100 \%$ using a terpene marker. The performance of inbred progeny in maritime pine seems also to confirm this hypothesis. In fact, Durel et al. [16] showed that the field survival rate of this species after a first growing season in the nursery was the same independently of the inbreeding level.

The level of relatedness found within the stand due to firstorder relationships (half-sibs and full-sibs) was low (around $3 \%$ ). Moreover, (a) different clusters of regeneration did not show, in general, a higher level of genetic relatedness than the stand as a whole; and (b) a weak within-population structure in natural regeneration (due to restricted seed dispersal, mainly) and a lack of spatial structure in the distribution of the genotypes of mature trees were found in a previous study in the same location [20]. Low within population relatedness has 
been found in most forest species analysed to date. For instance, Yazdani et al. [51] found that less than $10 \%$ of the seedlings clustered within $10 \mathrm{~m}$ from their mother trees in a 2-hectare Pinus sylvestris stand and, in Pinus clausa, Parker et al. [35] found that, even in populations with significant spatial genetic structure, most individuals were not closely related. The absence of tight kin groups in pine species usually avoids the potential for interactions such as kin selection and sib competition (but see [44]). However, a certain level of biparental inbreeding is common as shown by differences between the multilocus estimate of outcrossing and the average of the single-locus estimate using progeny arrays (e.g. Pinus sylvestris [10], Pinus attenuata [11], Pinus washoensis [30], Pinus contorta [31], Pinus leucodermis [32]).

Low genetic relatedness within a stand is usually caused by selection due to strong inbreeding depression or extensive gene flow [17]. Because inbreeding depression has been shown to affect lightly the survival of this species [16], an explanation based on gene flow seems more adequate. In the case of wind-dispersed forest species, gene flow is mainly due to pollen dispersal [7, 21, 43]. Considering the number of offspring that cannot be generated by the adult trees within the stand and assuming that when offspring matched only one adult in the stand it was the potential seed parent [15], an estimation of minimum pollen gene flow can be computed from our data. Minimum pollen flow within the stand was around $30 \%$. The true level of pollen gene flow in maritime pine was probably much higher than this minimum estimate, as reliable estimates are usually 2 to 4 fold the estimates based on only exclusion analysis [1]. Such a putative high gene flow by pollen would be enough to account for the low genetic relatedness found in our study.

Practical implications of these results centre on the low genetic relatedness found in a typical location of maritime pine in central Spain. Seed collection for reforestation in this stand seems adequate as a low level of inbreeding in the seedlots is expected and a high number of male parents probably contributes to the seed crop of each mother tree. However, studies on the fine-scale structure of this species in different management and ecological conditions are needed to define more precisely specific genetic conservation strategies.

Acknowledgements: We wish to thank D. Agúndez, S. Mariette, G. Le Provost, J.A. Cabezas, A. Álvarez, A. Piñera and F. del Caño for field and technical assistance and P.C. Grant who revised the grammar. The study was funded by the Cooperation project DGCNINIA CC00-0035 and the INIA project SC97-118. The first author was supported by a FPU scholarship from MECD (Ministerio de Educación, Cultura y Deporte).

\section{REFERENCES}

[1] Adams W.T., Burczyk J., Magnitude and implications of gene flow in Gene Conservation Reserves, in: Boyle T., Boshier D., Young A. (Eds.), Forest Conservation Genetics: Principles and Practice, CSIRO, Australia, 2000, pp. 215-224.

[2] Alderson G., Gibbs H., Sealy S., Parentage and kinship studies in an obligate brood parasitic bird, the brown-headed cowbird (Molothrus ater), using microsatellite DNA markers, J. Hered. 90 (1999) 182-190.
[3] Alía R., Gil L., Pardos J.A., Performance of 43 Pinus pinaster provenances on 5 locations in Central Spain, Silvae Genet. 44 (1995) 75-81.

[4] Alía R., Moro J., Denis J.B., Performance of Pinus pinaster provenances in Spain: interpretation of the genotype by environment interaction, Can. J. For. Res. 27 (1997) 1548-1559.

[5] Baradat Ph., Marpeau A., Le Pin maritime, Pinus pinaster. Biologie et génétique des terpènes pour la conaissance et l'amélioration de l'espèce, Ph.D. Thesis, Université Bordeaux I, Bordeaux, 1988.

[6] Blouin M.S., Parsons M., Lacaille V., Lotz S., Use of microsatellite loci to classify individuals by relatedness, Mol. Ecol. 5 (1996) 393-401.

[7] Boshier D.H., Chase M.R., Bawa K.S., Population genetics of Cordia alliodora (Boraginaceae), a neotropical tree. 3. Gene flow, neighbourhood, and population substructure, Am. J. Bot. 82 (1995) 484-490.

[8] Brenner C.H., Symbolic kinship program, Genetics 145 (1997) $535-542$.

[9] Brown A.H.D., Isozymes, plant population genetic structure and genetic conservation, Theor. Appl. Genet. 52 (1978) 145-157.

[10] Burczyk J., Mating system variation in a Scots pine clonal seed orchard, Silvae genet. 47 (1998) 155-158.

[11] Burczyk J., Adams W.T., Shimizu J., Mating patterns and pollen dispersal in a natural knobcone pine (Pinus attenuata Lemmon.) stand, Heredity 77 (1996) 251-260.

[12] Chakraborty R., Meagher T.R., Smouse P.E., Parentage analysis with genetic markers in natural populations. I. The expected proportion of offspring with unambiguous paternity, Genetics 118 (1998) 527-536.

[13] Costa M., Morla C., Saínz H. (Eds.), Los bosques ibéricos, Planeta, Barcelona, 1997.

[14] Dellaporta S.L., Wood J., Hicks J.B., A plant DNA minipreparation: Version II, Plant Mol. Biol. Rep. 1 (1983) 19-21.

[15] Dow B., Ashley M., Microsatellite analysis of seed dispersal and parentage of saplings in bur oak, Quercus macrocarpa, Mol. Ecol. 5 (1996) 615-627.

[16] Durel C.E., Bertin P., Kremer A., Relationship between depression and inbreeding coefficient in maritime pine (Pinus pinaster), Theor. Appl. Genet. 92 (1996) 347-356.

[17] Gandon S., Kin competition, the cost of imbreeding and the evolution of dispersal, J. Theor. Biol. 200 (1999) 345-364.

[18] Gerber S., Mariette S., Streiff R., Bodénès C., Kremer A., Comparison of microsatellites and AFLP markers for parentage analysis, Mol. Ecol. 9 (2000) 1037-1048.

[19] Gil L., Gordo J., Alía R., Catalán G., Pardos J.A., Pinus pinaster Aiton en el paisaje vegetal de la Península Ibérica, Ecología Fuera de Serie 1 (1990) 469-495.

[20] González-Martínez S.C., Gerber S., Cervera M.T., MartínezZapater J.M., Gil L., Alía R., Seed gene flow and fine-scale structure in a Mediterranean pine (Pinus pinaster Ait.) using nuclear microsatellite markers, Theor. Appl. Genet. 104 (2002) $1290-1297$

[21] Hamrick J.L., Murawski D.A., Nason J.D., The influence of seed dispersal mechanisms on the genetic structure of tropical tree populations, Vegetatio 107/108 (1993) 281-297.

[22] Jamieson A., Taylor S.S., Comparisons of three probability formulae for parentage exclusion, Anim. Genet. 28 (1997) 397-400.

[23] Kinlaw C.S., Neale D.B., Complex gene families in pine genomes, Trends Plant Sci. 2 (1997) 356-359.

[24] Ledig F.T., Genetic variation in Pinus, in: Richardson D.M. (Ed.), Ecology and biogeography of Pinus, Cambridge University Press, Cambridge, 1998, pp. 251-280.

[25] Loiselle B.A., Sork V.L., Nason J., Graham C., Spatial genetic structure of a tropical understory shrub, Psychotria officinalis (Rubiaceae), Am. J. Bot. 82 (1995) 1420-1425.

[26] Lynch M., Ritland K., Estimation of pairwise relatedness with molecular markers, Genetics 152 (1999) 1753-1766. 
[27] Mariette S., Chagné D., Decroocq S., Vendramin G.G., Lalanne C., Madur D., Plomion C., Microsatellite markers for Pinus pinaster Ait., Ann. For. Sci. 58 (2001) 203-206.

[28] Meagher T.R., Analysis of paternity within a natural population of Chamaelirium luteum. II. Patterns of male reproductive success, Am. Nat. 137 (1991) 738-752.

[29] Miguel I., González-Martínez S.C., Alía R., Gil L., Growth phenology and mating system of maritime pine (Pinus pinaster Aiton) in central Spain, Invest. Agr.: Sist. Rec. For. 11 (2002) 193-204.

[30] Mitton J.B., Latta R.G., Rehfeldt G.E., The pattern of inbreeding in Washoe pine and survival of inbred progeny under optimal environmental conditions, Silvae Genet. 46 (1997) 215-219.

[31] Mitton J.B., Linhart Y.B., Davis M.L., Sturgeon K.B., Estimation of outcrossing rate in ponderosa pine, Pinus ponderosa Laws., from patterns of segregation of protein polymorphisms and from frequencies of albino seedlings, Silvae Genet. 30 (1981) 117-121.

[32] Morgante M., Vendramin G.G., Olivieri A.M., Mating system analysis in Pinus leucodermis Ant.: detection of self-fertilizations in natural populations, Heredity 67 (1991) 197-203.

[33] Morgante M., Vendramin G.G., Rossi P., Olivieri A.M., Selection against inbreds in early life-cycle phases in Pinus leucodermis Ant., Heredity 70 (1993) 622-627.

[34] Muona O., Yazdani R., Rudin D., Genetic change between life stages in Pinus sylvestris: allozyme variation in seeds and planted seedlings, Silvae Genet. 36 (1987) 39-41.

[35] Parker K.C., Hamrick J.L., Parker A.J., Nason J.D., Fine-scale genetic structure in Pinus clausa (Pinaceae) populations: effects of disturbance history, Heredity 87 (2001) 99-113.

[36] Primmer C.R., Moller A.P., Ellegren H., Resolving genetic relationships with microsatellite markers: a parentage testing system for the swallow Hirundo rustica, Mol. Ecol. 4 (1995) 493-498.

[37] Queller D.C., Goodnight K.F., Estimating relatedness using genetic markers, Evolution 43 (1989) 258-275.

[38] Ritland K., Estimators of pairwise relatedness and inbreeding coefficients, Genet. Res. 67 (1996) 175-186.

[39] Ritland K., Marker-inferred relatedness as a tool for detecting heritability in nature, Mol. Ecol. 9 (2000) 1195-1204.
[40] Ronfort J., Couvet D., A stochastic model of selection on selfing rates in structured populations, Genet. Res., Camb. 65 (1995) 209-222.

[41] Salvador L., Alía R., Agúndez L., Gil L., Genetic variation and migration pathways of maritime pine (Pinus pinaster Ait.) in the Iberian Peninsula, Theor. Appl. Genet. 100 (2000) 89-95.

[42] Schnabel A., Parentage analysis in plants: mating systems, gene flow, and relative fertilities, in: Carvalho G.R. (Ed.), Advances in Molecular Ecology, IOS Press, The Netherlands, 1998, pp. 173-189.

[43] Schnabel A., Laushman R.H., Hamrick J.L., Comparative analysis of population genetic structure of two co-occurring tree species, Maclura pomifera (Moraceae) and Gleditsia triacanthos (Leguminosae), Heredity 67 (1991) 357-364.

[44] Schuster W.S.F., Mitton J.B., Relatedness within clusters of a birddispersed pine and the potential for kin interactions, Heredity 67 (1991) 41-48.

[45] Sorensen F.C., White T.L., Effect of natural inbreeding on variance structure in tests of wind-pollination Douglas-fir progenies, For. Sci. 34 (1988) 102-118.

[46] Taylor A.C., Cowan P.E., Fricke B.L., Cooper D.W., Genetic analysis of the mating system of the common brushtail possum (Trichosurus vulpecula) in New Zealand farmland, Mol. Ecol. 9 (2000) 869-879.

[47] Thompson E.A., Estimation of relationships from genetic data, in Rao C.R., Chakraborty R. (Eds.), Handbook of Statistics, Elsevier, Amsterdam, 1991, pp. 255-269.

[48] Thompson E.A., Meagher T.R., Parental and sib likelihoods in genealogy reconstruction, Biometrics 43 (1987) 585-600.

[49] Uyenoyama M.K., Holsinger K.E., Waller D.M., Ecological and genetic factors directing the evolution of self-fertilization, Oxford Surveys in Evolutionary Biology 9 (1993) 327-381.

[50] Wakamiya I., Newton R.J., Johnston J.S., Price H.J., Genome size and environmental factors in the genus Pinus, Am. J. Bot. 80 (1993) $1235-1241$

[51] Yazdani R., Lindgren D., Stewart S., Gene dispersion within a population of Pinus sylvestris, Scand. J. For. Res. 4 (1989) 295-306. 